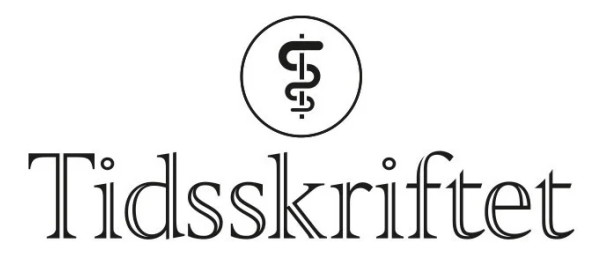

DEN NORSKE LEGEFORENING

\title{
Desentralisert legeutdanning ja takk!
}

KOMMENTAR

HÅVARD SVANQVIST SØNDENA

hsoo72@uit.no

Håvard Svanqvist Søndenå er medisinstudent ved Finnmarksmodellen, Universitetet i Troms $\emptyset$ Norges arktiske universitet.

Forfatteren har ikke oppgitt noen interessekonflikter.

La oss ikke snakke om desentralisert legeutdanning som noe nytt og ukjent. Jeg, med flere medstudenter i Finnmarksmodellen og Bodøpakken i ryggen, ønsker å friskmelde desentralisert utdanning fra å være fragmentert og annenrangs. Anna Midelfart og Kåre Reiten stiller i en debattartikkel spørsmålet om desentralisert legeutdanning kan bli for fragmentert (1). Vi ønsker å rette det vi mener er en feilaktig oppfatning om at desentraliserte studieløp ikke gagner oss studenter.

Ved Universitetet i Tromsø (UiT) er det frivillig påmelding til Bodøpakken og Finnmarksmodellen. Påmeldinga åpnes første studieår, og i de siste årene har vi sett at de fylles opp allerede da. Dette er fire år før vi skal bli en del av dem. Å studere desentralisert er nettopp vår egen prioritering. Vi velger desentraliserte løp fordi vi opplever det som mer attraktivt. Mens distriktet blør leger og Norge tapper andre land for tiltrengte leger, hvorfor står vi fortsatt og lurer på om det finnes faglig kvalitet og kompetente folk utenfor universitetenes rekkevidde?

For oss betyr å studere desentralisert å se pasienter som i større grad reflekterer virkeligheten der ute. Flere opplever på universitetssykehus å bli entusiastisk vinket bort til en pasient med en sjeldent tilstand - ting vi aldri kommer til å se igjen. Vi vil lære medisin som gjenspeiler realiteten, ikke det vi kan lese om som kuriositeter i Tidsskriftet.

Å ha desentralisert legeutdanning betyr at universitetene følger sitt samfunnsoppdrag: $\AA$ utdanne leger der de trengs. Det betyr at lokale studenter kan pendle hjem til bygda si i helgene. Det betyr å opprettholde bånd og relasjoner til plasser som kanskje i årevis har slitt med legemangel. Vi erfarer at Bodøfolk i stor grad søker Bodøpakken, og mange Finnmarkinger søker seg til Finnmarksmodellen.

Å studere desentralisert betyr gode forelesninger. Vi kommer til dyktige undervisere som ikke er trøtte av undervisningen de er pålagt å ha som en del av stillingen eller spesialister som snakker om detaljerte kirurgiske inngrep. Vi opplever ikke lengre at legen begynner med å spørre hvilket år vi går eller hva som skal undervises i dag. Vi kommer til godt planlagt klinisk undervisning med selvstendige konsultasjoner og tett oppfølging. Tidligere studenter erfarer lavere strykprosent i Bodø og Finnmark enn i Tromsø. 
Å studere desentralisert betyr å slippe å forholde seg til ti ulike undervisere i ett fag og at undervisere slipper å forholde seg til over 100 anonyme studenter. Det betyr å bli et fjes og et navn veiledere kjenner, å hilse på sine professorer i gangen, å drikke kaffe sammen på morgenmøter. Det betyr færre om beinet, god oppfølging og lite spisse albuer. Det betyr $\emptyset$ kt handlingsrom og mer mulighet for å ta ansvar. Det betyr pasienter som ikke er lei av å være prøvedukker for hele seks kull med medisinstudenter.

Det betyr kortere avstand mellom student og underviser. Det betyr lavere terskel for kurs, flere BEST-øvelser og prøveeksamener. Det betyr kontinuitet mellom professorer og studenter. Med andre ord: Desentralisert legeutdanning betyr, etter vår erfaring, en mindre fragmentert legeutdanning.

Hilsen samtlige studenter ved Finnmarksmodellen og Bodøpakken på femte og sjette studieår.

\section{LITTERATUR}

1. Midelfart A, Reiten K. Kan desentralisert legeutdanning bli for fragmentert? Tidsskr Nor Legeforen 2021; 141. doi: 10.4045/tidsskr.21.0614. [PubMed][CrossRef]

Publisert: 10. januar 2022. Tidsskr Nor Legeforen. DOI:10.4045/tidsskr.21.0866

(C) Tidsskrift for Den norske legeforening 2023. Lastet ned fra tidsskriftet.no 26. april 2023. 